\title{
The effect of mixture of banana pseudostem flour proportion on organoleptic properties, dietary fiber content, resistant starch, and antioxidants of canna starch-based food bar
}

\author{
${ }^{1,2 *}$ Welli, Y., ${ }^{2}$ Agnes, M., ${ }^{2}$ Yudi, P. and ${ }^{2}$ Yustinus, M. \\ ${ }^{1}$ Food Technology Studies Program, Department of Biology, Faculty of Science and Technology, \\ Universitas Terbuka, Jl. Cabe Raya, Pondok Cabe, Tangerang, Indonesia 15418 \\ ${ }^{2}$ Department of Food Technology and Agricultural Products, Faculty of Agriculture, University of Gadjah \\ Mada, Jl. Flora No. 1, Bulaksumur, 55281 Yogyakarta, Indonesia
}

\author{
Article history: \\ Received: 12 November 2019 \\ Received in revised form: 25 \\ December 2019 \\ Accepted: 31 December \\ 2019 \\ Available Online: 22 \\ February 2020
}

Keywords:

Pseudostem,

Food bar,

Organoleptic,

Dietary fiber,

Antioxidants

DOI:

https://doi.org/10.26656/fr.2017.4(3).382

\section{Introduction}

Changes in lifestyle drove people diet pattern leads to a tendency to consume fast food that possibly triggered abnormal lipid fraction that was called dyslipidemia such as hypercholesterolemia (Nie et al., 2017). This condition could occur because of fast food was usually rich in saturated fats and high in carbohydrates. The growth of hypercholesterolemia condition could be interpreted as an opportunity to develop or create nutritious snacks which were beneficial for health (antidyslipidemia). One of the snacks that met these criteria was high-fiber food bar. Food bar was food prepared by mixing various ingredients such as egg whites, margarine, powdered sugar, glucose syrup, starch, and others into rod-shaped dense food consumed in between the main meals or served as a snack food (Eka, 2013). Form of food bars was also selected because it was practical and had been developed. Nowadays, food bars became a trend as one of the healthy food products (Herawati et al., 2019).

Unfortunately, food bar sold in markets were processed from wheat flour and soy flour that were imported flour (Ladamay and Yuwono, 2014). Whereas food bar was able to be processed by utilizing the abundant and affordable local raw material. Some researchers claimed that the food bar could be processed by utilizing the Indonesian local flour such as pumpkin flour with mung bean flour (Fajri et al., 2013), tofu flour with yam flour (Rachmayani et al., 2017), and white millet flour with red bean flour (Anandito et al., 2016) and others.

One of the local materials that could be used as material for the production of the food bar is Cavendish Jepara 30 banana pseudostem flour (EBP) because it was rich in dietary fiber and antioxidants. EBP flour contained high levels of total dietary fiber $43.82 \pm 0.36 \%$ $\mathrm{db}$, soluble fiber $5.90 \pm 0.27 \% \mathrm{db}$, insoluble fibers 
$37.92 \pm 0.62 \% \mathrm{db}$, resistant starch (RS) $13.13 \pm 0.32 \% \mathrm{db}$, total phenolic components $132.81 \pm 2.14 \mathrm{mg} / 100 \mathrm{~g}$, and the antioxidant activity of $18.04 \pm 0.23 \%$ RSA (Yuliatmoko et al., 2019).

Meanwhile, canna starch was reported as a local starch containing high carbohydrates of approximately $84.34 \% \mathrm{db}$ so it was suitable for raw materials for food products (Pangesthy, 2009). However, dietary fiber content and antioxidants were reported to be low (Yuliatmoko et al., 2019). Based on the characteristics of those two materials, food bar made from the substitution of EBP flour with canna starch flour could be further developed. Material substitution probably changed the characteristics of the processed product so that the appropriate formulations was required. Formulations were very important in order to know the proper proportion of both flour in producing food bars that were high in dietary fiber and antioxidants but also preferred by potential consumers.

However, there was no research references that discussed the ability of EBP flour as dietary fiber and antioxidant enricher on canna starch-based food bar nor information on the ratio of canna starch flour: EBP flour to produce food bar. The purpose of this study was to determine the ability of EBP flour as dietary fiber and antioxidants enricher on canna starch-based food bar and to evaluate the best food bar based on sensory characteristics, the content of dietary fiber and total phenolic content, and physicochemical properties.

\section{Materials and methods}

\subsection{Materials}

Raw materials used were canna starch purchased from Mekar Sari Farmers Group, Sendangsari, Kulonprogo and Cavendish Jepara 30 banana pseudostem flour (EBP) processed from EBP CJ30 waste obtained from banana plantations PT Nusantara Trofical Farm (NTF) Terbanggi Great, Lampung, Indonesia. Additional materials for food bar included white eggs from chamart Lampung, 'Vita' branded margarine, 'Rose Bran' branded refined sugar, 'Epicerie Katrina' branded glucose syrups. All chemicals used were analytical grade chemicals.

\subsection{EBP flour processing}

Banana pseudostem (EBP) flour was processed following the procedure done by Yuliatmoko et al. (2019). Fresh harvested EBP obtained from banana plantation PT NTF then cut $30 \mathrm{~cm}$ with 7-inch stainless Zebra Smart cleaver. Then, EBP was washed with clean water and sliced into $2 \mathrm{~mm}$ thick by fruit vegetable slicer machine J23-Maksindo then the results were collected in a plastic container containing water basin for \pm 10 mins, drained, and then heated in a pan of boiling water for 10 mins. The sliced EBP inserted into the hollow while draining for 20 mins and then dried in an oven at a temperature of $55^{\circ} \mathrm{C}$ for $96 \mathrm{hrs}$. Next, sliced dried EBP was used to make flour using local engine Mitra Usaha Mandiri. Flour was sieved on 80 mesh. The product was EBP flour packed in airtight plastic container and stored in a cold room at $5^{\circ} \mathrm{C}$.

\subsection{Food bar formulations of canna-starch-EBP}

Food bar was formulated by preparing slight modification formulated by Pramitasari et al. (2015) (Table 1). Raw material of food bar which was originally used canna flour and agar-agar powder was replaced with canna starch and EBP flour. The use of EBP flour with concentrations of $0,5,10,15,20$, and $25 \mathrm{~g}$ aimed to determine the effect of the components of dietary fiber and antioxidants of EBP flour in enriching fiber and antioxidants of canna starch so that the resulting food bars that contained dietary fiber and antioxidants were sensory preferred by the panelists.

Food bar processing began by mixing all the ingredients such as egg white, glucose syrup, refined sugar, span 80, margarine, EBP flour and canna starch according to dose into the container glass bowl with mixer until a dough was formed. Next, the dough was molded with a size of $10 \mathrm{~cm} \times 3 \mathrm{~cm} \times 1 \mathrm{~cm}$ and put into a cake pan and then steamed for 5 minutes in a pan of boiling water container. Tray containing food bar baked in the oven with a temperature set at $80^{\circ} \mathrm{C}$ for 40 mins, $90^{\circ} \mathrm{C}$ for $30 \mathrm{mins}$, and a temperature of $100^{\circ} \mathrm{C}$ for 30 mins. Furthermore, food bars were removed from the

Table 1. Food bars formulation canna starch - EBP

\begin{tabular}{lcccccc}
\hline \multirow{2}{*}{ Material } & \multicolumn{6}{c}{ The ratio of canna starch-EBP flour } \\
\cline { 2 - 7 } & $100: 00: 00$ & $95: 05: 00$ & $90: 10: 00$ & $85: 15: 00$ & $80: 20: 00$ & $75: 25: 00$ \\
\hline Canna starch & $100 \mathrm{~g}$ & $95 \mathrm{~g}$ & $90 \mathrm{~g}$ & $85 \mathrm{~g}$ & $80 \mathrm{~g}$ & $75 \mathrm{~g}$ \\
EBP flour & $0 \mathrm{~g}$ & $5 \mathrm{~g}$ & $10 \mathrm{~g}$ & $15 \mathrm{~g}$ & $20 \mathrm{~g}$ & $25 \mathrm{~g}$ \\
Span 80 & $2 \mathrm{~g}$ & $2 \mathrm{~g}$ & $2 \mathrm{~g}$ & $2 \mathrm{~g}$ & $2 \mathrm{~g}$ & $2 \mathrm{~g}$ \\
Egg whites & $10 \mathrm{~g}$ & $10 \mathrm{~g}$ & $10 \mathrm{~g}$ & $10 \mathrm{~g}$ & $10 \mathrm{~g}$ & $10 \mathrm{~g}$ \\
Margarine & $30 \mathrm{~g}$ & $30 \mathrm{~g}$ & $30 \mathrm{~g}$ & $30 \mathrm{~g}$ & $30 \mathrm{~g}$ & $30 \mathrm{~g}$ \\
Fine sugar & $50 \mathrm{~g}$ & $50 \mathrm{~g}$ & $50 \mathrm{~g}$ & $50 \mathrm{~g}$ & $50 \mathrm{~g}$ & $50 \mathrm{~g}$ \\
Glucose syrup & $30 \mathrm{~g}$ & $30 \mathrm{~g}$ & $30 \mathrm{~g}$ & $30 \mathrm{~g}$ & $30 \mathrm{~g}$ & $30 \mathrm{~g}$ \\
\hline
\end{tabular}


oven and cooled for 30 mins. After being cold, food bar was packed in an airtight plastic container and stored in a refrigerator until further analyzed.

\subsection{Analysis of chemical composition}

Chemical analysis of food bar was performed three replications using procedure AOAC (AOAC, 1995), included, moisture content, ash, crude protein microKjeldahl, Soxhlet extraction of crude lipid, and total carbohydrates.

\subsection{Sensory analysis}

Sensory analysis used six samples, namely Canna Starch-based Food Bar substituted with EBP flour with ratio $0 \%, 5 \%, 10 \%, 15 \%, 20 \%$ and $25 \%$. The purpose of the sensory evaluation was to determine how much EBP flour could be substituted on canna starch that had similar characteristics with commercial food bar. Commercial food bar used as a comparison was strawberry-flavored Soyjoy. Sensory evaluation conducted was hedonic test with 5-options-hedonic scale, namely strongly dislike, dislike, neutral, like, extremely like.

\subsection{Measurement of dietary fiber}

Dietary fiber of food bar was measured following the method of Asp et al. (1983). Insoluble fiber (IDF) and soluble fiber (SDF) was analyzed using procedure, $1 \mathrm{~g}$ of flour sample and the duplicate inserted into the container of $0.5 \mathrm{~L}$ Erlenmeyer flask, then mixed $0.025 \mathrm{~L}$ of $0.1 \mathrm{M}$ sodium phosphate, $\mathrm{pH} \quad 6.0$, and the sample was deposited. Into the Erlenmeyer container, it was added $100 \mu \mathrm{L}$ termamyl $120 \mathrm{~L}$ origin Novo US industry and the container was covered with aluminum foil material. Next, a container of samples flour was interred in a shaking water bath at a temperature of $80^{\circ} \mathrm{C}$ for 15 mins. After it turned cool, the sample was added by $20 \mathrm{~mL}$ distilled water and the $\mathrm{pH}$ was adjusted to 1.5 with $\mathrm{HCI} 4$ M. Subsequently, the container containing the sample was added with $100 \mathrm{mg}$ of pepsin, then covered and incubated in a shaking water bath with a temperature of $40^{\circ} \mathrm{C}$ for 60 mins shaking. After it cooled, the container containing the sample was added with $20 \mathrm{~mL}$ of distilled water and the $\mathrm{pH}$ was adjusted to 6.8 with $\mathrm{NaOH} 4 \mathrm{M}$. Then into the container containing the sample was added with $100 \mathrm{mg}$ of pancreatin and the container was closed and incubated at $40^{\circ} \mathrm{C}$ water bath for 60 mins shaking. Subsequently, the $\mathrm{pH}$ was adjusted to 4.5 with $\mathrm{HCI}$, the solution was filtered using a crucible, which was dry and already weighed (P2) containing $0.5 \mathrm{~g}$ of dry celite and washed with $2 \times 10 \mathrm{~mL}$ distilled water. Residue of insoluble fiber (IDF) was washed with $2 \times 10 \mathrm{~mL}$ of $94 \%$ ethanol, dried at $105^{\circ} \mathrm{C}$ temperature overnight, then cooled and weighed and ash at $550^{\circ} \mathrm{C}$ overnight. Soluble fiber (SDF) was analyzed by the following procedure: $400 \mathrm{~mL}$ of $95 \%$ ethanol was added to the filtrate $60^{\circ} \mathrm{C}$ temperature, the precipitates were allowed to form for 60 mins. The solution was filtered, and then added with $2 \mathrm{x}$ $10 \mathrm{~mL}$ of $78 \%$ and $95 \%$ ethanol. Precipitate dried at $105^{\circ}$ $\mathrm{C}$ temperature overnight, then weighed and samples were ash as the IDF. Blank value was obtained by following the procedure without sample. The dietary fiber content was calculated using the formula:

$$
\begin{aligned}
& \mathrm{IDF}=\frac{(\mathrm{D} 1-\mathrm{I} 1-\mathrm{B} 1)}{\mathrm{W}} \times 100 \% \\
& \mathrm{SDF}=\frac{(\mathrm{D} 2-\mathrm{I} 2-\mathrm{B} 2)}{\mathrm{W}} \times 100 \%
\end{aligned}
$$

Total fiber content $=(1)+(2)$

Where $\mathrm{D}=\mathrm{g}$ weight after drying, $\mathrm{I}=\mathrm{g}$ weight after ashing, $\mathrm{B}=\mathrm{g}$ ash-free blank, and $\mathrm{W}=\mathrm{g}$ sample

\subsection{Measurement of Resistant Starch}

Resistant starch (RS) was measured using methods Goni et al. (1996). $0.1 \mathrm{~g}$ of sample food bar was inserted in the centrifuge tube with a lid, then added $10 \mathrm{~mL} \mathrm{KCL-}$ HCL buffer $\mathrm{pH} 1.5$ further vortex. Then into a container containing sample was added with $0.2 \mathrm{~mL}$ of pepsin and vortex Furthermore, the container containing the sample was put in the shaking water bath at temperature of $40^{\circ} \mathrm{C}$ for 60 mins. After it was cold, it was added into a container with $9 \mathrm{~mL}$ of $0.1 \mathrm{M}$ Trismaleate buffer $\mathrm{pH} 6.9$, then added $1 \mathrm{~mL}$ of $\alpha$-amylase. Then, the container was incubated for $16 \mathrm{hrs}$ at $37^{\circ} \mathrm{C}$ of shaking water bath. Next, the container was centrifuged at $3000 \times \mathrm{g}$ for $15 \mathrm{mins}$, and the supernatant was discarded, washed with $10 \mathrm{~mL}$ of distilled water, centrifuged again and the supernatant removed. Then, it was added with $3 \mathrm{~mL}$ of distilled water and $3 \mathrm{~mL}$ of $4 \mathrm{M} \mathrm{KOH}$. The container was put into the shaking water bath at room temperature for 30 mins. Furthermore, the container was added with $5.5 \mathrm{~mL}$ of 2 $\mathrm{M} \mathrm{HCl}$ and $3 \mathrm{~mL}$ of sodium acetate buffer $0.4 \mathrm{M}$ with a $\mathrm{pH}$ of 4.75 . Then into the container, it was added $80 \mathrm{~mL}$ amyloglucosidase, mixed well and put in a shaking water bath temperature of $60^{\circ} \mathrm{C}$ for $45 \mathrm{~m}$, then centrifuged $3000 \times \mathrm{g}$ for 15 mins. Then the supernatant was stored in a volume tube. Next, the residue was added with $10 \mathrm{~mL}$ of distilled water and centrifuged. Then, the supernatant was collected and mixed with $50 \mathrm{~mL}$ of distilled water. Then the standard curve was composed from glucose solution (10-60 ppm) of ki GOD PAP. Subsequently, 0.5 $\mathrm{mL}$ sample, blank, and standards were pipetted into the tube. Then it mixed with $1 \mathrm{~mL}$ reagent kit GOD PAP. Then it was put into a shaking water bath temperature of $37^{\circ} \mathrm{C}$ for 30 mins. Subsequently, the sample, blank, and standard calibrated at $510 \mathrm{~nm}$. RS was calculated with the aid of a standard curve. Resistant starch was calculated as glucose $\times 0.9 \mathrm{mg}$. 


\subsection{Measurement of total phenolic content}

Total phenolic content of the food bar was measured using methods of Senter et al. (1989). Preparation of standard solution of gallic acid: (a) the production of gallic acid stock solution $20 \mathrm{mg} \cdot 100^{-1} \mathrm{~mL}$; (b) The dilution was done by setting up 6 screw-threaded test tubes were each then filled with a stock solution in sequence as follows: $2 \mathrm{~mL}, 1.6 \mathrm{~mL} ; 1.2 \mathrm{~mL} ; 0.8 \mathrm{~mL} ; 0.4$ $\mathrm{mL}$; and $0 \mathrm{~mL}$; (c) the addition of distilled water into each tube in the following order: $0 ; 0.4 \mathrm{~mL} ; 0.8 ; 1.2 \mathrm{~mL}$; $1.6 \mathrm{~mL}$; and $2 \mathrm{~mL}$; (d) each tube was taken as $0.2 \mathrm{~mL}$; (e) the addition of $1 \mathrm{~mL}$ of folin reagent $\mathrm{Na}_{2} \mathrm{CO}_{3}$ solution of $0.8 \mathrm{~mL}$ of $7.5 \%$ and $3 \mathrm{~mL}$ of distilled water each tube then performed using vortex; (f) incubated for $0.5 \mathrm{hr}$; (g) calibration with absorbance of $750 \mathrm{~nm}$. Total phenolic contents were determined by means: (a) taking $1 \mathrm{~mL}$ sample of the food bar; (b) addition of $1 \mathrm{~mL}$ of folin reagent, $0.8 \mathrm{~mL}$ of $\mathrm{Na}_{2} \mathrm{CO}_{3} 7.5 \%$, and addition $3 \mathrm{~mL}$ of water and then performed using vortex mixing; (c) incubation for $0.5 \mathrm{hr}$; (d) absorbance with a spectrophotometer calibration $\lambda 750 \mathrm{~nm}$

\subsection{Determination of antioxidant activity}

Antioxidant activity was measured using the DPPH free radical scavenging activity method Hatona et al. (1988) and Yen and Chen (1995). Two hundred mg of sample was inserted into a test tube and a screw-threaded tube was added it $5 \mathrm{~mL}$ of methanol, then extracted by vortex for 60 mins. Furthermore, $250 \mu \mathrm{L}$ supernatant was mixed with $5 \mathrm{~mL}$ of methanol and $1 \mathrm{~mL}$ of $0.1 \mathrm{mM}$ DPPH solution and put in a glass test tube with a lid and incubated at room temperature for 30 mins. Furthermore, the absorbance was calibrated with spectrophotometer at $\lambda 517 \mathrm{~nm}$

\subsection{Determining the best treatment}

The best treatment was determined by the sensory test, the content of soluble fiber, and antioxidants by applying the principle of the method de Garmo (1984) in Diniyah et al. (2012). In sensory and chemical tests a weighting system was applied. The value in the sensory test was stated with criterion 3 for a highly preferred product, and 1 for an unwanted product. The value of food fiber and antioxidants was expressed as a value of 3 for the highest levels and a value of 1 for the lowest levels. The grading of the weights of each attribute was adjusted to the importance of the role of these attributes in the selection. Weighted values for sensory test by $30 \%$ while the dietary fiber and antioxidants were each given a weighting of $40 \%$ and $30 \%$.

\subsection{Subheading analysis of physical properties of food} bars: the color and the level of hardness

Food bar color analysis was done by reading the fraction of color such as the value of the brightness ( $\left.\mathrm{L}^{*}\right)$, redness $\left(a^{*}\right)$ and yellowness $\left(b^{*}\right)$ of samples of food bar with a Minolta instrument chromamometer as methods Hutchings. (1999). While testing the level of hardness was done by putting the sample in the sample container, then it was put on pressure using tool in which the measured values was recorded by the instrument in the form of a graph. The level of hardness of food bar was measured using a Zwick Universal Testing Machine tools ZO.5 type and expressed in Newton (N) unit.

\subsection{Experimental design}

The parameters observed such as proximate analysis (moisture, ash, protein, carbohydrates and lipid) and chemical analysis such as levels of dietary fiber, resistant search, total phenolic and antioxidant activity. Each parameter was triplicated. All research data were analyzed using one-way analysis of variance followed by Least Significant Difference Test using SPSS 20.0.

\section{Results and discussion}

\subsection{The chemical and physical properties of canna starch and EBP flour}

The chemical properties of raw materials were very important to know so that the nutritional content of macronutrient food bars produced met the standard of food bar as the total number of calories recommended by BPOM and USDA. The physical properties such as color raw materials was needed to know because it was very closely related to consumer preference towards food bars produced. The chemical and physical properties of canna starch and EBP flour as a raw material for producing food bars were presented in Table 2.

From Table 2 below, EBP flour contained dietary fiber and antioxidants that were higher than canna starch so that it was able to enrich the content of dietary fiber and antioxidants than canna starch. While the canna starch contained carbohydrates and had a very high degree of brightness. From the characteristics of the two ingredients, one suitable alternative product can be developed, namely a high-fiber food bar and antioxidants that are preferred by consumers. Food bar was chosen because this product is classified as a simple product, easy to make, and can be modified according to purpose. High-fiber food bars and antioxidants can be processed by determining the proportion of the mixture that fits between the two ingredients, namely EBP flour and canna starch. Judging from the characteristics of the two ingredients, canna starch is suitable to be used as the 
basic ingredient of a food bar. While EBP flour is more suitable as a substitute material because it is rich in food fiber. Thus the use of EBP flour is expected to increase the content of food fiber and antioxidant food bar produced. Meanwhile, canna starch as a base material that is rich in carbohydrates with higher brightness levels is expected to produce food bars that have colors that attract consumers' interest (Castilho et al., 2010). However, color is a determining aspect in whether or not the product is by consumers (Ladamay and Yuwono, 2014). On the other hand, the choice of high-fiber food bars and antioxidants because they are classified as functional food products is currently experiencing a trend of increasing consumption by the public (Herawati et al., 2019). Functional foods high in dietary fiber and antioxidants are very beneficial for health because they can improve plasma lipid profiles such as cholesterol reduction (Stephen et al., 2017; Cheurfa et al., 2019).

Table 2. Chemical and physical properties of canna starch and EBP flour

\begin{tabular}{|c|c|c|}
\hline Parameter & Canna Starch $^{1}$ & $\mathrm{EBP}^{1}$ \\
\hline \multicolumn{3}{|l|}{ Chemistry: } \\
\hline The water content $(\% \mathrm{wb})$ & $17.7 \pm 0.21$ & $6.19 \pm 0.12$ \\
\hline The ash content $(\% \mathrm{db})$ & $0.03 \pm 0.00$ & $26.01 \pm 0.01$ \\
\hline The protein content $(\% \mathrm{db})$ & $0.29 \pm 0.00$ & $0.89 \pm 0.03$ \\
\hline Fat content $(\% \mathrm{db})$ & $0.17 \pm 0.00$ & $7.22 \pm 0.06$ \\
\hline Carbohydrate content $(\% \mathrm{db})$ & $81.8 \pm 0.21$ & $59.69 \pm 1.89$ \\
\hline $\begin{array}{l}\text { Levels of total dietary fiber }(\% \\
\mathrm{db})\end{array}$ & $7.37 \pm 0.33$ & $43.82 \pm 0.36$ \\
\hline Soluble fiber $(\% \mathrm{db})$ & $1.43 \pm 0.13$ & $5.90 \pm 0.27$ \\
\hline Insoluble fiber $(\% \mathrm{db})$ & $5.94 \pm 0.41$ & $37.92 \pm 0.62$ \\
\hline Resistant starch $((\% \mathrm{db})$ & $13.32 \pm 0.64$ & $13.13 \pm 0.32$ \\
\hline $\begin{array}{l}\text { Components of total phenolic } \\
(\mathrm{mg} / 100 \mathrm{~g})\end{array}$ & $0.18 \pm 0.06$ & $132.81 \pm 2.14$ \\
\hline $\begin{array}{l}\text { The antioxidant activity ( } \% \\
\text { RSA) }\end{array}$ & $7.24 \pm 0.24$ & $18.04 \pm 0.23$ \\
\hline \multicolumn{3}{|l|}{ Physical: } \\
\hline Brightness (L *) & $89.47 \pm 0.20$ & $59.41 \pm 0.48$ \\
\hline Redness $(\mathrm{a} *)$ & $4.73 \pm 0.03$ & $8.16 \pm 0.20$ \\
\hline Yellowness $(\mathrm{b} *)$ & $2.15 \pm 0.08$ & $12.54 \pm 0.41$ \\
\hline
\end{tabular}

${ }^{1}$ Data source from Yuliatmoko et al. (2019).

$\mathrm{EBP}=$ Banana pseudostem, wb = wet basis, $\mathrm{db}=$ dry basis, and RSA = radical scavenging activity.

\subsection{The chemical composition}

The results of ANOVA of the chemical composition of canna starch - EBP-based food bars showed that the treatment group affected the chemical composition of food bar significantly at $p<0.05$. The test results showed the difference among the treatment groups that there was significant difference among the treatment groups (Table 3 ). The water content and carbohydrate of food bars tended to decrease with the increasing ratio of EBP flour. This was due to the higher water content and starch carbohydrates of canna compared to water content of the EBP flour (Yuliatmoko et al., 2019)

In addition, the proportion of canna starch compared to six food bars were higher than EBP flour. Canna starch could increase the starch content of food bars that served as water-binding agent so that the water content food bar had also increased. Starch molecule had big hydroxyl groups so that the ability to bind water was also strong (Ladamay and Yuwono, 2014). The lower carbohydrate content of food bars with increasing EBP flour indicated that substitution at high starchy foods could produce low-carbohydrate food bar.

Ash, fat, and protein of 6 food bars tended to increase with increasing the ratio of EBP flour. This was due to the added EBP flour contained high level of ash, fat, and protein when compared with canna starch (Yuliatmoko et al., 2019). The ash content indicated mineral content of a material (Sudarmadji et al., 1989)

Based on international standards, commonly called food bar or granola bar should be per 100 grams of water containing nutrients such as $3.9 \%, 10.1 \%$ protein, $19.8 \%$ fat, $64.4 \%$ carbohydrate (USDA, 2019). Referring to these standards, canna starch-based food bar which was substituted with EBP flour had met the nutrient content in the form of fat and carbohydrates but did not meet the water and protein content. The high water content in the food bar from this study was due to the water content of the basic ingredients of food bar namely canna starch which was very high, which is $17.7 \pm 0.21 \% \mathrm{wb}$ (Table 2 ). This canna starch water content did not meet the criteria

Table 3. The chemical composition of food bars canna starch-EBP

\begin{tabular}{cccccc}
\hline \multirow{2}{*}{$\begin{array}{c}\text { The ratio of canna starch: } \\
\text { EBP flour }\end{array}$} & The water & Ash content & Fat & Protein & Carbohydrate \\
\hline $100: 00: 00$ & $8.34 \pm 0.05^{\mathrm{f}}$ & $0.43 \pm 0.00^{\mathrm{a}}$ & $9.89 \pm 0.02^{\mathrm{a}}$ & $1.15 \pm 0.00^{\mathrm{a}}$ & $80.19 \pm 0.05^{\mathrm{d}}$ \\
$95: 05: 00$ & $8.18 \pm 0.03^{\mathrm{e}}$ & $0.97 \pm 0.01^{\mathrm{b}}$ & $10.20 \pm 0.04^{\mathrm{b}}$ & $1.21 \pm 0.00^{\mathrm{b}}$ & $79.52 \pm 0.07^{\mathrm{d}}$ \\
$90: 10: 00$ & $7.88 \pm 0.09^{\mathrm{d}}$ & $1.92 \pm 0.02^{\mathrm{c}}$ & $10.52 \pm 0.01^{\mathrm{c}}$ & $1.44 \pm 0.00^{\mathrm{c}}$ & $78.24 \pm 0.11^{\mathrm{c}}$ \\
$85: 15: 00$ & $6.95 \pm 0.05^{\mathrm{c}}$ & $2.68 \pm 0.01^{\mathrm{d}}$ & $10.93 \pm 0.00^{\mathrm{d}}$ & $1.50 \pm 0.00^{\mathrm{d}}$ & $77.95 \pm 0.46^{\mathrm{c}}$ \\
$80: 20: 00$ & $6.60 \pm 0.29^{\mathrm{b}}$ & $2.96 \pm 0.02^{\mathrm{e}}$ & $12.03 \pm 0.07^{\mathrm{e}}$ & $1.56 \pm 0.01^{\mathrm{e}}$ & $76.85 \pm 0.46^{\mathrm{b}}$ \\
$75: 25: 00$ & $5.62 \pm 0.03^{\mathrm{a}}$ & $3.89 \pm 0.00^{\mathrm{f}}$ & $14.27 \pm 0.01^{\mathrm{f}}$ & $2.02 \pm 0.05^{\mathrm{f}}$ & $74.19 \pm 0.47^{\mathrm{a}}$ \\
\hline
\end{tabular}

$\mathrm{EBP}=$ banana pseudostem. Different superscript letters behind values in the same column show significant differences $(\mathrm{p}$ $<0.05)$ 
of starch or flour according to the Indonesian National Standard (SNI 01-6057-1999), namely the maximum water content of starch products is $16 \%$ (Indrianti et al., 2019). However, the water content of food bar produced has fulfilled the criteria of semi-solid food that was 20$40 \%$ (Sakidja, 1989). Food bar or snack bar is a type of solid food that is classified as semi-solid food (Hartaty et al., 2017). Unlike the very high food bar water content, the protein content of the food bar produced is very low. This was due to the two main ingredients of food bar namely canna starch and EBP flour which contain low protein. However, the low protein content has been previously thought and the focus of this research was developing a food bar that contained food fiber and antioxidants. To increase the protein food bar it is recommended to add flour or other ingredients that contain high protein.

\subsection{The dietary fiber content and $R S$}

The results of ANOVA of the fiber content and resistant starch of canna starch - EBP based food bar showed that the treatment group affected the content of dietary fiber and RS significantly at $p<0.05$. The test results showed the significant difference among treatment groups (Figure 1). Levels of insoluble fiber, soluble fiber, and total dietary fiber food bar tended to increase with the increase in the ratio of EBP flour. This was due to the levels of insoluble fiber, soluble fiber, and total dietary fiber EBP flour were greater than canna starch. Based on the content of dietary fiber, food could be classified into the fiber food and high-fiber foods. Fiber foods were foods containing dietary fiber not less than $3 \mathrm{~g} / 100 \mathrm{~g}$. High-fiber foods were foods containing dietary fiber not less than $6 \mathrm{~g} / 100 \mathrm{~g}$ (BPOM, 2011). Under this definition, the canna starch-based food bar which was substituted with EBP flour could be classified into fiber food, namely food bars processed with the ratio of canna starch with EBP flour 95: 5 and the high-fiber food was a food bar processed by the ratio of canna starch with EBP flour 95: 10, 95: 15, 95:20, and 95:25. The high-fiber food in a food bar came from the substitution of EBP flour because flour contained high fiber food, which was $43.82 \pm 0.36 \% \mathrm{db}$ (Yuliatmoko et al., 2019). Food bars containing dietary fiber could be involved as an alternative food to cope with the condition of dyslipidemia as the dietary fiber, especially dietary fiber soluble could improve the lipid profile such as lowering total cholesterol and LDL cholesterol (Galisteo et al., 2008; Erukainure et al., 2012; Marounek et al., 2017).

Levels of RS ( $\% \mathrm{db}$ ) of canna starch-based food bar which were substituted with a varied and significant as presented in Table 4. Resistant starch level of food bar tended to increase with increasing the ratio of EBP flour. This was due to the higher level of RS of added EBP flour and it was more resistant to damage during processing. RS had a physiological effect that could improve the condition of dyslipidemia by lowering cholesterol levels, binds bile, laxative, and improved SCFA (Cummings et al., 1996; Marsono, 1998; Stephen et al., 2017).

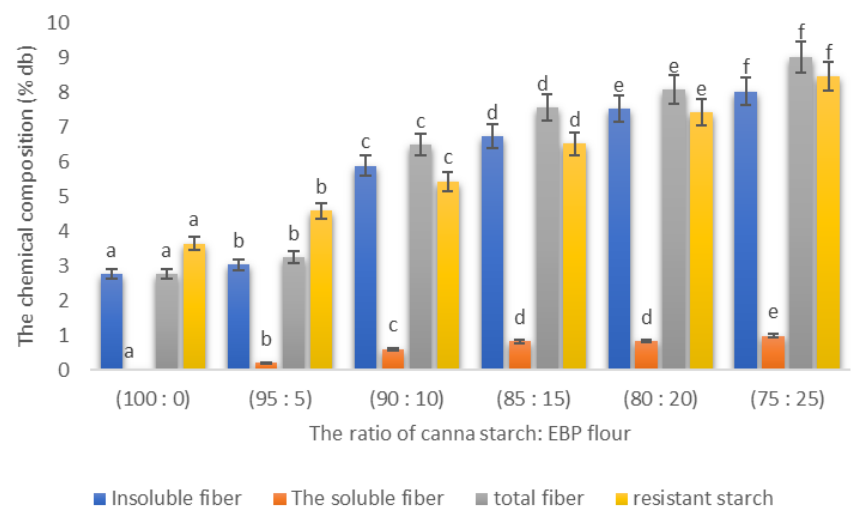

Figure 1. Composition of dietary fiber and resistant starch of canna starch- EBP food bar. Different superscript notations on the same color images show significant differences $(p<0.05)$.

Table 4. Components of total phenolic and antioxidant activity Canna starch food bars - EBP

\begin{tabular}{ccc}
\hline \multirow{2}{*}{$\begin{array}{c}\text { The ratio of canna } \\
\text { starch: EBP flour }\end{array}$} & \multicolumn{2}{c}{ The chemical composition } \\
\cline { 2 - 3 } & $\begin{array}{c}\text { Total phenolic } \\
\text { compounds } \\
(\mathrm{mg} / 100 \mathrm{~g})\end{array}$ & $\begin{array}{c}\text { The antioxidant } \\
\text { activity } \\
(\% \mathrm{RSA})\end{array}$ \\
\hline 100:00:00 & $62.74 \pm 0.45^{\mathrm{a}}$ & $2.99 \pm 0.00^{\mathrm{a}}$ \\
$95: 05: 00$ & $73.34 \pm 0.35^{\mathrm{b}}$ & $4.48 \pm 0.00^{\mathrm{b}}$ \\
$90: 10: 00$ & $101.85 \pm 0.92^{\mathrm{c}}$ & $5.97 \pm 0.00^{\mathrm{c}}$ \\
$85: 15: 00$ & $105.75 \pm 0.64^{\mathrm{d}}$ & $6.97 \pm 0.77^{\mathrm{d}}$ \\
$80: 20: 00$ & $117.60 \pm 0.95^{\mathrm{e}}$ & $7.96 \pm 0.77^{\mathrm{e}}$ \\
$75: 25: 00$ & $123.19 \pm 0.71^{\mathrm{f}}$ & $11.44 \pm 0.77^{\mathrm{f}}$ \\
\hline
\end{tabular}

EBP = banana pseudostem, RSA radical scavenging activity. Different superscript letters behind values in the same column show significant differences $(\mathrm{p}<0.05)$.

\subsection{The antioxidant activity}

The result of ANOVA of total phenolic and antioxidant activity of canna starch - EBP food bar showed that the treatment group affected the total phenolic components and antioxidant activity $(\mathrm{p}<0.05)$. The test results showed the difference among the treatment groups as seen in Table 4. Total phenolic content of the food bar tended to increase with the increase in the ratio of EBP flour. This was due to the levels of total phenolic of EBP flour which were higher than canna starch.

The antioxidant activity of food bar tended to increase with increasing the ratio of EBP flour. This increase in antioxidant activity was thought to originate 
from the higher total phenolic content of EBP compared to canna starch (Table 2). The antioxidant activity of a food ingredient was positively correlated with the total content phenolic (Wettasinghe and Shahidi, 2000; Cheng et al., 2013). Components of antioxidant polyphenols like flavans, anthocyanins, quercetin, myricetin, kaempferol, and resveratrol could lower plasma lipids such as plasma triglycerides and LDL cholesterol (Qin et al., 2009; Sayago-Ayerdi et al., 2014; Chen et al., 2019). Thus, substituting EBP flour for canna starch in canna starch food bar-EBP can increase the total phenolic component of food bar so that the antioxidant activity of food bar-EBP also increases. The high antioxidant component in canna starch food bars - EBP can be utilized to improve plasma lipids so that they are beneficial for health.

\subsection{Sensory quality of food bars}

The results of ANOVA of sensory quality of canna starch - EBP food bars showed that the treatment group significantly affected the sensory quality of food bar. The test results showed the difference among treatment groups (Figure 2). Food bars were derived from the treatment of canna starch-EBP flour 90:10 and 85:15 had the highest color score of $3.16 \pm 0.11$ and $3.12 \pm 0.08$ or neutral preference level. The both scores were not significantly different. From the analysis it was found that the addition concentrations of 10 and 15 of EBP flour on the formula bar made the color food bar more preferred by the panelists. However, the increased concentration of EBP flour caused the panelist preference level of the color attribute.

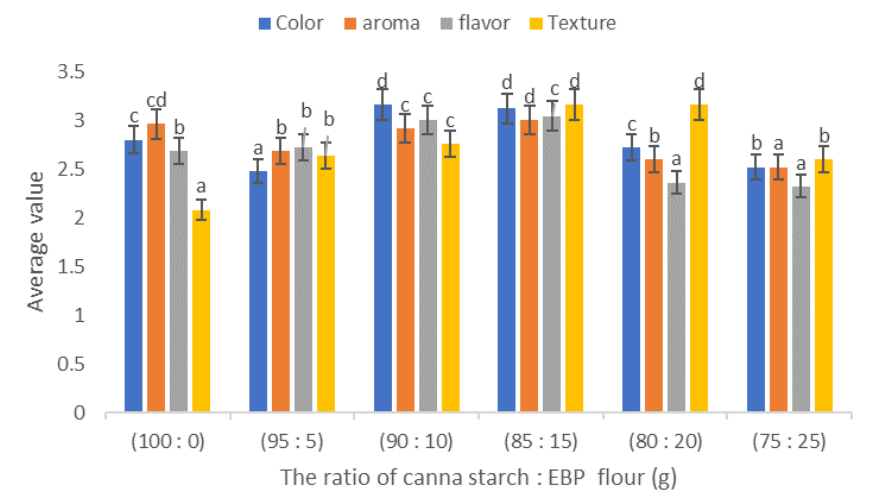

Figure 2. Hedonic food bars test results of canna starch EBP. Different superscript notations on the same color images show significant differences $(\mathrm{p}<0.05)$.

The similar phenomenon was also demonstrated by the aroma attributes. Food bars were derived from the treatment of canna starch EBP flour substituted with a ratio 85:15 and 100: 0 to obtain the highest score of the scent, which was $3.00 \pm 0.06$ and $2.96 \pm 0.14$ or neutral preference level. The both scores were not significantly different. The concentration of 15 EBP flour in food bar caused food bar obtained preference response on the highest aroma and the response decreased with reduced or increased concentrations of EBP flour. During the processing of food bars, it was suspected that chemical reactions produced a particular aroma (Ladamay and Yuwono, 2014). One aroma formed during processing, furaneol, was formed by the Mailard reaction (Makfoeld et al., 2002).

Meanwhile, the different phenomenon demonstrated by the preference level of panelists on flavor and texture attributes. Food bar that got the highest response to the attributes of flavor that was $3.00 \pm 0.06$ and $3.04 \pm 0.18$ or neutral preference level was a food bar that was processed by the ratio of canna starch and EBP flour $90: 10$ and $85: 15$. The both scores were not significantly different. The greater the EBP flour in food bar could increase preference response till the optimum level. The increasing concentration of EBP flour could decrease the level of preference. The fall in the level of preference for flavor attributes by increasing EBP was allegedly linked to a high-fiber component on EBP flour. Furthermore, food bar that got the highest score of texture attribute from panelists were $3.16 \pm 0.12$ and $3.16 \pm 0.10$ or neutral preference level from food bar that was processed by the ratio of canna starch and EBP flour 85:15 and 80: 20. The both scores were not significantly different. The greater the EBP flour in food bar could increase preference response till the optimum level. The increasing concentration of EBP flour could decrease the level of preference of texture attribute. This condition was thought to be linked with higher content of dietary fiber in a food bar. The increasing proportion of dietary fiber carboxy methyl cellulose (CMC) had been reported to improve fracture/texture of food bars made from tapioca flour and mung bean flour (Ladamay and Yuwono, 2014). Insoluble fiber was fiber foods was reported to affect the hardness of the food product (Santala et al., 2014 cited in Yan et al., 2015). However, the increased concentration of materials containing highfiber food such as tofu flour with a total dietary fiber content of $50.35 \%$ were reported to produce snack bar with rugged texture and less favored by panelists (Rachmayani et al., 2017). Insoluble dietary fiber had been reported to reduce the acceptance of the sensory by panelists (Robin et al., 2012) because it produced hardtexture product. This was presumably related to the role of insoluble fiber that could cause low levels of free water in the product.

\subsection{Determining the best food bars}

The best food bar was determined based on the selection of observational parameters according to 
research priorities, which then determine the weight, worst value, and best value (De Garmo, 1984; Diniayah et al., 2012). The observation parameter used to choose the best food bar was a sensory test, the content of soluble dietary fiber, and total phenolic compounds (Table 5). The evaluation resulted the best food bar was food bar with canna starch: EBP flour 85:15. This food bar had the highest value compared to other five food bars.

Table 5. The best food bars were based on hedonic test parameters, soluble food fiber, and total phenolic compounds

\begin{tabular}{cccc}
\hline \multirow{2}{*}{$\begin{array}{c}\text { The ratio of canna } \\
\text { starch: EBP flour }\end{array}$} & $\begin{array}{c}\text { Hedonic } \\
\text { test }\end{array}$ & $\begin{array}{c}\text { Soluble } \\
\text { dietary fiber }\end{array}$ & $\begin{array}{c}\text { Total } \\
\text { phenolic }\end{array}$ \\
\hline 100:00:00 & 1 & 1 & 1 \\
$95: 05: 00$ & 2 & 1 & 1 \\
$90: 10: 00$ & 2 & 1 & 2 \\
$85: 15 * *$ & 3 & 2 & 2 \\
$80: 20: 00$ & 2 & 2 & 2 \\
$75: 25: 00$ & 1 & 3 & 3 \\
\hline
\end{tabular}

The score criteria for rating each parameter: $1=$ lowest score, $2=$ medium score, and $3=$ high score

*weight criteria for each parameter: hedonic test of 30; soluble fiber by 40 and total phenolic by 30 .

**The best treatment of election result
The best food bar had a characteristic color: brightness $\left(\mathrm{L}^{*}\right)$ of $52.52 \pm 0.60$, and the level of hardness by $5.08 \pm 1.95$ (Table 6 ). When compared to the control food bar, Soyjoy, the best food bar had a higher brightness level. This was presumably because the brightness level of raw materials of the best food bar was higher than the control food bar, but had a lower level of hardness than the control food bar, 8.96 \pm 2.80 . The texture of food was determined by the moisture content, fat, carbohydrate, and protein constituent (Fellows, 2009). Insoluble fiber also affected the hardness of a product, the more insoluble fiber contained made the appearance tended to be harder and rough (Santala et al., 2014; Yan et al., 2015). Fiber was able to bind large amounts of water, upon heating would trap the other components so that the texture of the product became compact. The formation of the texture of food products was affected by the processing methods, the kinds of products used, and the ingredients are added (KramLich, 1971). More details of nutritional content of best food bar and control were presented in Table 6 .

\section{Conclusion}

The substitution of EBP flour on canna starch-based

Table 6. The chemical, physical and sensory attributes of canna starch - EBP food bar vs control

\begin{tabular}{lcc}
\hline \multicolumn{1}{c}{ Parameter } & food bar & Control (Soyjoy) \\
\hline Chemical composition: & & \\
Servings (g/serving) & $30^{* * *}$ & 30 \\
Total Energy (kcal)/100 g & 416.17 & $433.33^{\mathrm{a}}$ \\
The water content $(\% \mathrm{wb})$ & $6.95 \pm 0.05$ & - \\
The ash content $(\% \mathrm{db})$ & $2.68 \pm 0.01$ & - \\
The protein content $(\% \mathrm{db})$ & $1.50 \pm 0.00$ & $13.33^{\mathrm{a}}$ \\
Fat content $(\% \mathrm{db})$ & $10.93 \pm 0.00$ & $15^{\mathrm{a}}$ \\
Carbohydrate content $(\% \mathrm{db})$ & $77.95 \pm 0.46$ & $63.33^{\mathrm{a}}$ \\
Levels of total dietary fiber $(\% \mathrm{db})$ & $7.58 \pm 0.13 * *$ & - \\
Soluble fiber $(\% \mathrm{db})$ & $0.83 \pm 0.07$ & $10^{\mathrm{a}}$ \\
Insoluble fiber $(\% \mathrm{db})$ & $6.75 \pm 0.14$ & - \\
Resistant starch $(\% \mathrm{db})$ & $6.54 \pm 0.24$ & - \\
${ }^{\mathrm{b}}$ Total phenolic compounds $(\mathrm{mg} / 100 \mathrm{~g})$ & $105.75 \pm 0.64$ & $46.66^{\mathrm{b}}$ \\
Physical : & & \\
Brightness $(\mathrm{L} *)$ & $52.52 \pm 0.60$ & $47.92 \pm 6.75$ \\
Redness $(\mathrm{a} *)$ & $9.08 \pm 0.15$ & $13.44 \pm 2.61$ \\
Yellowness $(\mathrm{b} *)$ & $17.03 \pm 0.28$ & $28.68 \pm 4.67$ \\
Broken power $(\mathrm{N})$ & $5.08 \pm 1.95$ & $8.96 \pm 2.80$ \\
Sensory: & & \\
Color & $3.12 \pm 0.08$ & $4.49 \pm 0.16$ \\
Aroma & $3.00 \pm 0.06$ & $4.41 \pm 0.14$ \\
Flavor & $3.04 \pm 0.18$ & $4.44 \pm 0.08$ \\
Texture & $3.16 \pm 0.12$ & $3.92 \pm 0.18$ \\
\hline
\end{tabular}

$\mathrm{wb}=$ wet basis; $\mathrm{db}=$ dry basis. aInformation of nutritional Value "Soyjoy" on packaging, bisoflavones **Included in foods high in fiber

***To meet the daily needs of adult fiber of $30 \mathrm{~g} /$ person/day, it is necessary to consume 7 food bars @ $30 \mathrm{~g} / \mathrm{serving}$ 
food bar could increase the levels of ash content, fat, and protein of food bar but lowered levels of water content and carbohydrates. The higher concentration of EBP flour tended to contribute to the higher ash content, fat, protein and lower the water content and carbohydrates. Based on the scoring test against sensory characteristics, levels of soluble dietary fiber and total phenolic, it was obtained that food bars processed with the treatment of canna starch: banana pseudostem flour of 85:15 was selected as the best food bar which had similar characteristics with commercial food bar products (Soyjoy). The substitution of banana pseudostem flour on canna starch-based food bar could increase the levels of soluble dietary fiber, total dietary fiber, resistant starch, total phenolic, and antioxidant activity. The greater the ratio of banana pseudostem flour, the greater the tendency of the levels of dietary fiber, resistant starch, total phenolic and antioxidant activity.

\section{Conflict of Interest}

The authors declare no conflict of interest.

\section{Acknowledgments}

This research was carried out as part of doctoral program. This research was carried out as part of doctoral program. The financial support of the Ministry of Research, Technology and Higher Education through Domestic Postgraduate Education Scholarships was gratefully acknowledged.

\section{References}

Anandito, R.B.K., Siswanti., Nurhartadi, E. and Hapsari, R. (2016). Formulation of food bars made flour from white millet (Panicum milliaceum) and red bean flour. AGRITECH, 36(1), 23-29. https:// doi.org/10.22146/agritech.10680

AOAC. (1995). Official Methods of Analysis. 16th ed. Washington DC: Association of Official Analytical Chemists.

Asp, N.G., Johansson, C.G., Hallmer, H. and Siljestroem, M. (1983). Rapid enzymatic assay of insoluble and soluble dietary fiber. Journal of Agricultural Food Chemistry, 31, 476-482. https:// doi.org/10.1021/jf00117a003

Badan Pengawas Obat dan Makanan (BPOM). (2011). Regulation of the Head of Supervisory Board Drug and Food of the Republic of Indonesia Year 2011 on Oversight Claims in the Labeling and Advertising of processed food, Jakarta. Retrieved on Nov 10, 2019 from http://standarpangan.pom.go.id/dokumen/ peraturan/2011/2011-HK_03.1.23.11.11.09605Pencantuman_Informasi_Nilai_Gizi.pdf.
Badan Pengawas Obat dan Makanan (BPOM). (2016). Regulation of the Head of the Republic of Indonesia Drug and Food Supervisory Agency Number 9 of 2016 concerning Reference to Processed Food Nutrition Labels, Jakarta. Retrieved on Nov 10, 2019 from https://asrot.pom.go.id/img/Peraturan/ Peraturan\%20Kepala\%20BPOM\%20No.209\% 20Tahun\%202016\%20tentang\%20Acuan\% 20Label\%20Gizi.pdf

Castilho, F., Fontanari, G.G. dan Batistuta, J.P. (2010). Evaluation of some functional properties of sweet lupine flour (Lupinus albus) and pigeonpea (Cajanus cajan (L) Millsp) and its use in the production of ham. Food Science and Technology, 30(1), 68-75. https://doi.org/10.1590/S0101-20612010005000007

Chen, Z., Li, S., Fu, Y., Li, C., Chen, D. and Chen, HA. (2019). Rabinoxylan structural characteristics, interaction with gut microbiota and potential health functions. Journal of Functional Foods, 54, 536551. https://doi.org/10.1016/j.jff.2019.02.007

Cheng, A., Chen, X., Jin, Q., Wang, W., Shi, J. and Liu, Y. (2013). Comparison of phenolic content and antioxidant capacity of red and yellow onions. Czech Journal of Food Sciences 31(5), 501-508. https:// doi.org/10.17221/566/2012-CJFS

Cheurfa, M., Abdallah, H.H., Allem, R., Noui, A., PicotAllain, C.M.N. and Mahomoodally, F. (2019). Hypocholesterolaemic and antioxidant properties of Olea europaea L. leaves from Chlef province, Algeria using in vitro, in vivo and in silico approaches. Food and Chemical Toxicology, 123, 98 -105. https://doi.org/10.1016/j.fct.2018.10.002

Cummings, J.H., Beatty, E.R. and Kingman, S.H. (1996). Digestion and physiological properties of resistant starch in the human large bowel. British Journal of Nutrition, 75(5), 733-747. https:// doi.org/10.1079/BJN19960177

De Garmo, Sullivan, E.P.W.G. and JR Canada, J.R. (1984). Engineering economy the $7^{\text {th }}$ edition. New York: Macmillan Publishing Company.

Diniyah, N., Wijanarko, S.B. and Purnomo, H. (2012). Brown sugar syrup processing from Palm SAPS (Borossus Flabellifer L.). Journal of Food Technology and Industry, 23(1), 53-57.

Eka, F. (2013). The influence of the use of flour and banana puree against quality characteristics bananabased solid food. Nutrition Food Research Journal, $36,127-134$.

Erukainure, O.L., Adeboyejo, F.O., Elemo, G.N. and Ebeuhi, O.A. (2012). Modulation of lipid peroxidation, hypolipidemic, and antioxidant activities in brain tissues of diabetic rats by fiber- 
enriced. Journal of Acute Disease, 1(1), 42-46. https://doi.org/10.1016/S2221-6189(13)60010-4

Fajri, R., Basito. and Muhammad, D.R.A. (2013). Physicochemical and organoleptic Characteristic of pumpkin (Cucurbita maxima) food bars supplement with soy flour and mung bean bean flour as emergency food product. Journal of Agricultural Technology, 6(2), 103-110.

Fellows, P.J. (2009). Food processing technology, principle and practice 3rd ed. England: Woodhead Publishing Limited. doi.org/10.1533/9781845696344

Galisteo, M., Duarte, J. and Zarzuelo, A. (2008). Effects of dietary fibers on disturbances clustered in themetabolic syndrome. Journal of Nutritional Biochemistry, 19(2), 71-84. https://doi.org/10.1016/ j.jnutbio.2007.02.009

Goni, I., Garcia-Diz L., Manas, E. and Saura-Calixto, F. (1996). Analysis of resistant starch: a method for foods and food products. Food Chemistry, 56(4), 445 -449. https://doi.org/10.1016/0308-8146(95)00222-7

Hartaty, M.M., Parnanto, N.H.R., Yudisthira, B. and Sanjaya, A.P. (2017). Physicochemical and sensory characteristics of snack bar added of Yellow pumpkin flour (Cucurbita moschata), corn flour (Zea mays) and Jackfruit puree (Artocarpus heterophyllus). Journal of Agricultural Product Technology, 10(2), 99-109.

Hatona, T., Kagawa, H., Yasuhara, T. and Okuda, T. (1988). Two new flavonoids and other constituents in licoricee root: their relative Affects astringency and radical scavenging. Chemical Pharmaceutical Bulletin, 36(6), 1090-2097. https://doi.org/10.1248/ cpb.36.2090

Herawati, E.R.N., Miftakhussolikhah, M., Pusporini, A.R. and Murdiati, A. (2019). Sensorial and chemical characterization of the snack bar with variation of gembolo flour (Dioscorea bulbifera) and arrowroot starch (Marantha arundinaceae L.). Food Research, 3(5), 564-569. https://doi.org/10.26656/ fr.2017.3(5).099

Hutchings, J.B. (1999). Food color and appearance. $2^{\text {nd }}$ ed. Maryland: Aspen Pub. https:// doi.org/10.1007/978-1-4615-2373-4

Indrianti, N., Afifah, N. and Sholicahah, E. (2019). The Production of Composite Flour from Canna/ Arrowroot Starch and Pumpkin Flour as Flat Noodle Ingredient. Biopropal Industry, 10(1), 49-63.

KramLich, W.E. (1971). Meat and meat products. In Price, J.F. and Schweigert, B.S. (Eds.). The science of meat and meat products. $2^{\text {nd }}$ ed. San Francisco: Ads W. H. Freeman and company.
Ladamay, N.A. and Yuwono, S.S. (2014). The Use of Local Materials in the Production Foodbars (Study of Tapioca: Green Bean Flour CMC Ratio and Proportion). Journals Food and Agro-Industry, 2(1), 67-78.

Makfoeld, D., Djagal, W.M., Hastuti, P., Anggrahini, S., Raharjo, S., Sastrosuwignyo, S., Suhardi, Harsono, BC, Hadiwiyoto, S. and Tranggono. (2002). Dictionary of Food and Nutrition Terms. Yogyakarta: Kanisus.

Marounek, M., Voleka, Z., Rivanova, E.S., Taubner, T., Pebriansyah, A. and Skova, D.D. (2017). Comparative study of the hypocholesterolemic and hypolipidemic activity of alginate and amidated alginate in rats. International Journal of Biological Macromolecules, 105(Part 1), 620-624. https:// doi.org/10.1016/j.ijbiomac.2017.07.077

Marsono, Y. (1998). Resistant Starch: Formation, metabolism and its nutritional aspects. AGRITECH, $18,29-35$.

Nie, Q., Hu, J., Gao, H., Fan, L., Chen, H. and Nie, S. (2017). Polysaccharide from Plantago asiatica L. attenuates hyperglycemia, hyperlipidemia and affects colon microbiota in type 2 diabetic rats. Food Hydrocolloids, 86, 34-42. https://doi.org/10.1016/ j.foodhyd.2017.12.026

Pangesthy, L.T. (2009). Utilization of canna starch (canna edulis) on making fresh noodles as an attempt diversification of non-rice food. Media Education, Nutrition and Culinary, 1, 1-6.

Pramitasari, G. (2015). Substitution effect of wheat flour order canna with against chemical properties, physical and sensory canna bar. Yogyakarta: Gadjah Mada University, MSc. Thesis.

Qin, Y., Xia, M., Ma, J., Hao, Y.T., Liu, J., Mou, H.Y., Cao, L. and Ling, W.H. (2009). Anthocyanin supplementation improves serum LDL- and HDLcholesterol concentrations associated with the inhibition of cholesteryl ester transfer protein in Subjects dyslipidemic. American Journal of Clinical Nutrition, 90(3), 485-492. https://doi.org/10.3945/ ajcn.2009.27814

Rachmayani, N., Rahayu, W.P., Faridah, D.N. and Siregar, E. (2017). A high-fiber bar snack flourbased pulp (okara) and purple yam flour. Journal of Technology and Industry Food, 28(2), 139-149. https://doi.org/10.6066/jtip.2017.28.2.139

Robin, F., Schuchmann, H.P. and Palzer, S. (2012). Dietary fiber in extruded cereals: Limitations and opportunities. Trends in Food Science and Technology, 28(1), 23-32. https://doi.org/10.1016/ j.tifs.2012.06.008 
Sakidja. (1989). Food Chemistry. Jakarta, Indonesia: Department Education and culture.

Santala, O., Kiran, A., Sozer, N., Poutanen, K. and Nordlund, E. (2014). Enzymatic modification and particle size reduction of wheat bran improves the mechanical properties and structure of bran-enriched Extrudates expanded. Journal of Cereal Science, 60 (2), 448-456. https://doi.org/10.1016/ j.jcs.2014.04.003

Sayago-ayerdi., Mateos, R., Ortiz-Basurto, R.I., Largo, C., Serrano, J., Granado-Serrano, A.B., Sarria, B., Bravo, L. and Tabernero, M. (2014). Effects of consuming diets Agave Azul containing dietary fiber and Jamaica. Food Chemistry, 148, 54-59. https:// doi.org/10.1016/j.foodchem.2013.10.004

Senter, S.D., Robertson, J.A. and Meredith, F.I. (1989). Phenolic compounds of the Mesocarp of cresthaven peaches during storage and ripening. Journal Food Science, 54(5), 1259 - 1268. https://doi.org/10.1111/ j.1365-2621.1989.tb05968.x

Stephen, A.M., Champ, M.M.J., Cloran, S.J., Fleith, M., Lieshout, L.V., Mejborn, H. and Burley, V.J. (2017). Dietary fibre in Europe: current state of knowledge on definitions, Sources, recommendations, intakes and relationships to health. Nutrition Research Reviews, 30(2), 149-190. https://doi.org/10.1017/ S095442241700004X

Sudarmadji, S. and Bambang, H.S. (1989). Analysis of food ingredients and Agriculture. Yogyakarta: Liberty.

United States Department Agriculture (USDA). (2019). National Nutrient Database for Standard reference. Full Report (All Nutrients) 19 105, A Granola Bar. Retrieved on March 17, 2019 from USDA website: http://ndb.nal.usda.gov.

Wettasinghe, M. and Shahidi, S. (2000). Scavenging of Reactive Oxygen species and DPPH-free radicals by extract of borage and evening meals Primerose. Food Chemistry, 70(1), 17-26. https:// doi.org/10.1016/S0308-8146(99)00269-1

Yan, X., Ran, Y.E. and Chen, Y.E. (2015). Blasting extrusion processing: The Increase of soluble dietary fiber content and extraction of soluble-fiber polysaccharides from wheat bran. Food Chemistry, 180, 106-115. https://doi.org/10.1016/ j.foodchem.2015.01.127

Yen, G.C. and Chen, H.Y. (1995). Antioxidant activity of various tea extracts in relation to their antimutagenicity. Journal Agricultural Food Chemistry, 43, 27-32. https://doi.org/10.1021/ jf00049a007
Yuliatmoko, W., Murdiati, A., Pranoto, Y. and Marsono, Y. (2019). Chemical and functional properties of cavendish Jepara 30 (Musa cavendishii) banana pseudostem flour due to blanching and soaking in sodium bisulphite solution. Pakistan Journal Nutrition, 18(10), 936-945. https://doi.org/10.3923/ pjn.2019.936.945 